\title{
Why Does It Have to Be so Flashy? Student Perspectives on Academic Tasks
}

\author{
Nicola Dunham \\ Unitec Institute of Technology, Auckland, New Zealand
}

\begin{abstract}
Student academic identity represents the willingness and commitment to engage with academic ways of knowing, being, and doing and as such in an important aspect of becoming academically literate. This paper reports on findings associated with student engagement with academic tasks in the undertaking of a field-based programme of early childhood initial teacher education in Aotearoa (the Māori name for New Zealand). Data were collected from students, teacher educators, and associate teachers using qualitative tools including open-ended questionnaires and group and individual interviews. Participation was gathered from four tertiary providers of field-based early childhood initial teacher education within Aotearoa. Additional contextual data being sought from the wider early childhood community in which field-based study was situated. Interpretation of the findings indicates that student academic identity is influenced by the nature of academic tasks and the associated experiences of dissonance as students move from the comfort zone of everyday ways of being, knowing, and doing to those required of the academe. Relevance of academic tasks with future professional practice was also identified as significant to student engagement. The research findings reveal that attention to academic tasks within wider programme curriculum design in field-based programmes is significant in supporting students achieving successful academic outcomes.
\end{abstract}

Keywords: student academic identity, discourse, field-based initial teacher education (FBITE), Aotearoa (New Zealand)

\section{Introduction}

The aim of this paper is to provide insight into student perspectives of academic study with the intention that such insights be used to inform understanding of student academic identity through the direct representation of student experience. Student academic identity refers to the willingness and commitment demonstrated towards the appropriation of academic values and practices within a sense of self during the experience of becoming academically literate. The academic values and practices in question relate to those associated with field-based initial teacher education (FBITE) within the field of early childhood education (ECE).

\section{Field-based Programme Design}

To fully appreciate the issue of academic identity for students win FBITE, it is necessary to first have an understanding of the context in question. Early childhood initial teacher education within Aotearoa (the Māori name for New Zealand) has a strong foundation within field-based programmes which draw on regular student

Nicola Dunham, Ph.D. candidate, Department of Education, Unitec Institute of Technology. 
experience working, as volunteers or paid employees, and within early childhood centres as part of their teacher education. This field-based option for credentialing in the ECE sector is of particular interest as on a regular basis these students move between the practices of the academe and those of early childhood centres; continually negotiating ways of being, knowing, and doing from one context to another. It is further acknowledged that the draw of such students into the academe in the first place is that of obtaining a professional credential for practice outside of the academe.

A programme of FBITE consists of study across sites other than the main institutional provider's campus (Kane, 2005). For students, these study sites typically consist of the academic classroom, the work-experience early childhood centre for regular weekly teaching practice experience, and additional early childhood centres forming the practicum elements of the programme. This crude outline, however, misses the significance of the roles that students undertake within these various sites of learning. For instance, during classroom and practicum-based learning, students may clearly hold the label of "student". In their work experience centres, they may actually be regarded as students, or as volunteers, as relief workers, or even as teachers in a paid or unpaid capacity. Participation in these multiple sites of learning draws on a degree of adaptability on the part of the students so that they can adequately function in these multiple roles, across multiple contexts, and within multiple and possibly contested Discourses (Gee, 2001; Lea, 1998; Mezirow, 2000). The term Discourse in this context, using a big D, draws on the work of Gee (2000) around the behaviour of social groups and as such relates to the wider concepts of social participation, agency, and identity. Understanding how student academic identity fits within the overall experience of FBITE is deemed important to the wider issues of student engagement, retention, and success.

The credentialing of teachers in the early childhood sector in Aotearoa has faced a turbulent history, which remains unsettled even to this day. Despite claims that participation in quality ECE is critical to building firm foundations for children's later learning and development (Ministry of Education, 2002), the credentialing of early childhood teachers as a contributing factor to quality provision remains open to the whim of governmental preferences at any one time. The requirements to introduce professional registration and increase the number of qualified early childhood teachers, established within the strategic plan Pathways to the Future (Ministry of Education, 2002), were a step towards establishing equality within the early childhood sector. To raise the profile of early childhood teachers, the move to attain pay parity with the compulsory sector early childhood teachers gained momentum with a requirement that early childhood teachers attain qualification at bachelor degree level, despite the two-year diploma being the agreed minimum credential to meet registration requirements (Ministry of Education, 2002). It was the academe that took on the role of providing authority and legitimacy to the credentialing process, and with this academisation of initial teacher education comes the increasing challenge of navigating academic Discourse (Gee, 2001).

\section{Academic Literacies}

By joining the academe, students are agreeing to participate in the Discourse of the community, which is defined by a system of symbolic action defined by the academic community and communicated through a distinct body of practices (Gee, 2001). Academic literacies relate to becoming conversant in the discursive practices of the academic community and as such are a necessary part of success in academic study. Becoming academically literate means that students will need to learn the ways of being, doing, and knowing constituting the Discourse of the academic community. Academic Discourse in its simplest form revolves around the 
generation and dissemination of knowledge.

Within academic Discourse, the generation of knowledge is primarily associated with methods of inquiry, critical thinking, analysis and evaluation of information or data, and sharing of findings within the relevant discipline community. There is a reliance on reading and writing for this dissemination of knowledge. Academic Discourse consists of rules and expectations, the most widely promoted being that of ownership of knowledge and the detrimental act of plagiarism. Becoming academically literate involves not only being aware of the rules and expectations of the academic community, but also being able and willing to follow them. It is well documented that many students, particularly those at the beginning of higher education, find the rules of the academic community daunting and challenging especially if they have had limited prior exposure to academic Discourse (Gourlay, 2009; Ivanič, Edwards, Satchwell, \& Smith, 2007; Lea \& Street, 1998).

Through the duration of their study, students become more exposed to the social practices of the academic community, typically moving from using the prior generated knowledge of a discipline through to developing and generating new knowledge through their own research as students. This exposure also facilitates deeper involvement and participation within the academic community (Wenger, 1998), and becoming literate relates to these degrees of involvement and participation within a given community. Movement from the periphery of the community of practice is facilitated through the enhancement of competency in the required Discourse (Gee, 2001; Smith, 2009). Through being exposed to and participating in the academic community, students, as social actors, are opened up to constructing new meaning and adopting new ways of mediating the world and as such new ways of locating self (Stets \& Burke, 2005).

It is acknowledged that social actors may be negotiating ways of being within a number of communities at any one time and through entry to a new community social actors learn that Discourses vary between contexts and communities (Reveles \& Brown, 2008). For the students, this means that they are not only learning to navigate the Discourse of the academic community, but they are also participants in other communities, such as work sites, social communities, and the community of family. Also, known as communities of practice, such social groupings are defined as "groups of people who share a concern or a passion for something they do and learn how to do it better as they interact regularly" (Wenger, n.d., para. 2). Membership of multiple communities of practice is referred to as a nexus of interconnected communities in which a person may participate as forming a "living landscape of practices" (Wenger, 1998, p. 165). Participation in a landscape of practices reflects not only the multiplicity of roles that are held by social agents, but also the complexity inherent in attributing meaning to the world of everyday experience (Kilgore, 2001), and negotiate identity as ways of being a person.

\section{Student Academic Identity}

Navigating academic study requires competency in academic literacies that are seen as academic practices, which include the values, attitudes, feelings, and social relationships, which connect to and shape interactions with the academic world (Perry, 2012). A comprehensive definition of academic literacies, therefore, acknowledges the academic context in which specific literacies practices are situated. This understanding of literacies as socially situated acknowledges the place of power, agency, and identity as students learn to read the academic word and the academic world (Street, 2003). Through this line of argument, developing an academic identity within and towards academic practices is argued as a constituent part of becoming academically literate (Lea, 2004; Northedge, 2003). Within the literature, it is identified that the concept of 
student academic identity is associated with five core elements of self-theories, achievement indicators, agency beliefs, motivation, and dispositions.

\section{Self-theories}

Self-theories are based on a combination of internal and externally derived knowledge and are associated with a belief in one's own self to behave in a particular way (Bandura, 1995). Self-esteem is an important aspect of self-theories and relates to the emotional dimension of self-perceptions (Krause, Bochner, \& Duchesne, 2003). Self-esteem may be positive (high) or negative (low), and in the academic context, self-esteem is linked with self-comparison with fellow students, the relationships formed within the academic environment potentially influencing student engagement, and participation in academic tasks. Self-efficacy also relates to self-esteem in the academic context (Krause et al., 2003). Higher self-efficacy is associated with higher levels of self-confidence, which are important for managing challenges and stresses within academic study. High self-efficacy is associated with a personal sense of agency, influence, and control to attain successful outcomes. Conversely, low self-esteem is associated with feelings of powerlessness and inadequacy, which may impact on further elements of academic identity, such as motivation.

Perceptions of future or possible selves are also important in academic situations. According to Hamman, Gosselin, Romano, and Bunuan (2010, p. 1351), future or possible selves involve "casting the self in terms of the future and possible also implies a goal that is anticipated and may be realized". Future or possible self-emerge is derived from desires and hopes, as well as fears and reservations for the self, which are said to be specific and significant rather than any imagined role (Markus \& Nurius, 1986). In relation to student academic identity, the future aspirations for self have an influencing role on motivation, self-regulation, and self-concepts associated with the learning behaviours.

\section{Achievement Indicators}

Achievement indicators refer to the degree to which a student realises his/her educational goals (Azar, 2013), and achievement indicators act to gauge the likelihood of meeting with academic success. In relation to student academic identity, achievement indicators provide essential messages informing a sense of self in terms of confidence, efficacy, and a future sense of possible self associated with the likelihood of achieving academic goals (Was, Al-Harthy, Stack-Oden, \& Isaacson, 2009).

Feedback is an example of an achievement indicator, involving the provision of information about performance or understanding enabling students to gain insight into their academic ability (Schunk \& Mullen, 2013; Timperley, 2013). Feedback can be both formative and summative in that it can be used to inform a student as to areas for future development prior to a final measure of success (Brown \& Race, 2012). Positive feedback in terms of areas of student success can lead to an increase in positive self-perceptions, and increases in motivation. Negative feedback, on the other hand, in the form of poorer than anticipated or desired grades or lower expectations on competency measures, can be related to negative impacts on self-beliefs and lowered motivation and engagement in academic study (Timperley, 2013).

\section{Agency Beliefs}

Agency beliefs refer to personal strategies and how students use them in order to attain academic success. Agency beliefs are associated with knowing what to do to achieve academic success, and are closely aligned with but remain separate from the motivation to achieve (Walls \& Little, 2005). In this way, agency within the academic context relates to degrees of activity/passivity and perceptions of personal control that students hold 
in relation to learning (Ryan, 2009). In terms of student actions, such agency relates to strategies, such as time-keeping, organisation, taking notes, using effective research skills to gather information, managing academic workloads and assessment deadlines, and the prioritising of commitments (Lai, 2011a).

Agency beliefs utilise self-regulatory processes through which a student as a proactive agent directs his/her own learning (Zimmerman, 2002). Self-regulated learners demonstrate autonomy through knowing how and when to seek help in achieving goals, with help-seeking behaviour being defined as "requests for assistance, clarification, information, and checking-of-work from teachers" (Calarco, 2011, p. 865). As such agency beliefs and self-regulation processes comprise the thoughts, feelings, and behaviours a student holds towards goal achievement.

An associated feature of agency and self-regulation is that of procrastination. Academic procrastination, also referred to as temporal discounting, is said to consist of "failing to perform an academic activity within a desired timeframe or postponing until the last minute activities one needs to complete" (Jackson, 2012, p. 20). Acts of academic procrastination are counter to effective self-regulation and have been associated with the need for constant reassurance, defensiveness, self-handicapping behaviours, and poor academic decision-making (Berzonsky, 2004; Was et al., 2009). Furthermore, it is also negatively associated with academic self-efficacy and reportedly most likely to occur in relation to academic reading, writing, and examination preparation (Jackson, 2012).

\section{Motivation}

Motivation, as an element of student academic identity, consists of a number of components including beliefs around task value, goal orientation, and affect. In terms of task value, motivation relates to whether the students are setting out on a learning pathway of their own choosing, intrinsic motivation, or one in which they are fulfilling the academic expectations of others, usually parents, termed external motivation (Dweck, 2000). Intrinsic motivational properties consist of orientations towards learning, such as whether learning is regarded as meaningful and enjoyable, and hence, the commitment and willingness displayed in engaging with academic practices. Furthermore, student academic motivation is said to be influenced by factors, such as the student's self-concept and self-efficacy, making a connection across to academic identity as self-theory (Rodriguez, 2009).

Motivation is also associated with goal orientation. Achieving goals is associated with the personal approaches taken within learning situations, and whether students engage in actions of pursuing or avoiding learning situations. Through connection with goal orientation, achievement indicators relate to student motivation towards learning situations. As such, goal orientation relates to student academic identity in a number of ways; motivationally and the achievement of personal learning goals; self-theories, in terms of comparison of self with peers on academic tasks; agency, in terms of energy, the desire to learn, and activity applied to learning; and dispositions, associated with intellectual curiosity (Howell \& Watson, 2007). Motivation enables continued engagement in depth of thinking, and is associated with the dispositions of effort and persistence (Lai, 2011b; Rodriguez, 2009).

\section{Dispositions}

Dispositions consist of "habits of mind" (Lai, 2011b, p. 16), including values and beliefs, strategies and intentions (Freeman, 2003). The dispositions and qualities a student holds are examples of personal resources influencing navigation of, and participation in the social world. Examples of dispositions associated with a 
positive academic identity include inclination to open oneself to experience, preparedness to explore, and preparedness to listen (Barnett, 2007, p. 102). Such dispositions are associated with orientations to the world, readiness to move forward, to take action, and as such relate to motivation, agency, and self-theories. In relation to the academic context, general academic dispositions include attitudes towards working hard, paying attention, participation, commitment to academic study, ways of recovering from set-backs, how challenges are approached, and points of focus, such as seeing personal failings or challenges to overcome (Bandura, 1995). Dispositions also relate to student attitudes towards knowledge construction in the form of information processing styles. These cognitive strategies influence how events are perceived, experienced, and interpreted, the meaning that is attached to them, and in turn future patterns of responding to like situations. These styles of processing relate to how receptive students are to new knowledge and are also associated with perceptions of knowledge and intelligence (Dweck, 2000), including "what knowledge is, how knowledge is gained, and the degree of certainty with which knowledge can be held" (Brownlee \& Berthelsen, 2006, p. 17).

\section{Methodology}

As the overall aim of the research was to investigate student academic identity, an interpretive methodology was chosen utilising qualitative data collection methods. The interpretive methodology was informed by the principles of phenomenology in which attention is given to the life world (Van Manen, 1997) or the "everyday world of practical experience" (Ladkin, 2005, p. 112). In this life world, it is within the subjective experiences of participants that phenomena are given meaning. Meaning is derived from how social actors look at their experiences with, or in the words of Schutz (1967), "Meaning is a certain way of directing one's gaze at an item of one's own experience" (p. 42). The interpretive researcher gathers the meaning of lived experiences by asking how and why questions; thereby, systemically uncovering the nature of subjective experiences of phenomena in the form of rich detailed descriptions of lived experience from a reflective stance (Cohen, Manion, \& Morrison, 2007; Finlay, 2009; Yin, 2009).

In relation to the investigation of identity within an educational environment, it is argued that there are three groups of contextual features playing an influencing role within the development of identity in an educational environment: the self, pedagogy, and the institution (Vermunt, 2005). The context of self being aligned with the personal experiences of academic identity of students; the pedagogical context being aligned with the academe; and the institution being perceived at the wider societal level of the ECE sector. Given the importance of context in relation to identity development, research participation was sought not only from students for whom academic identity was a lived experience, but in addition from across academic, community, and socio-political contexts. The contexts and participation sought for the research are represented in Figure 1.

Participants were identified according to specified criteria within purposive sampling procedures (Patton, 2002). In relation to student participants, the first and final semesters of study were deemed significant points of transition in which identity is most open to investigation (LeCourt, 2004). Further to this point, it is argued that by reading identity "against the grain" (Hall, 1996, p. 18), it is possible to engage in the narratives of experience of crossing over into new structures of meaning, positions of being, and ways of looking at and interpreting oneself and the world (Topp, 2000). Student data were gathered through the use of open-ended questionnaires distributed to first-year and final-year students undertaking a field-based Bachelor of Teaching (ECE) from across four tertiary institutions in Aotearoa. The open-ended questionnaires were designed to 
acknowledge, but not specifically compare, the differences between student experiences commencing academic study with those of students coming towards the end of their academic study.

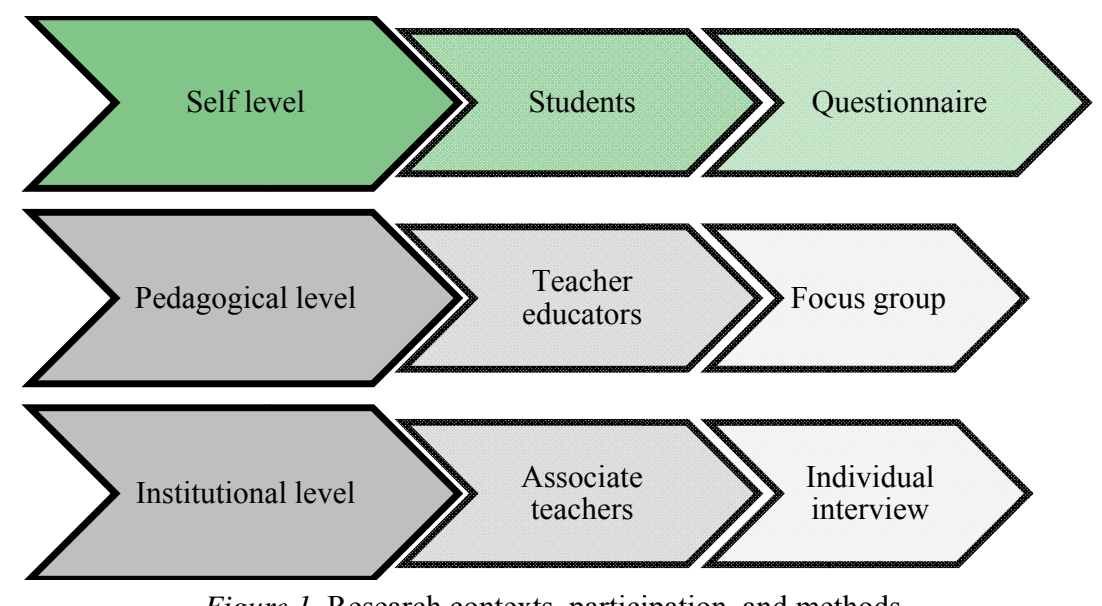

Figure 1. Research contexts, participation, and methods.

Data were collected from 205 student participants: 134 first-year students in their first semester of study; and 71 final-year students in their final semester of study. There was an overall response rate of $66 \%$ for first-year and $45 \%$ for the final-year student samples. Additional participation was sought from group interviews or focus groups with teacher educators involved in the delivering of the programme of FBITE from each of the four institutions. Further participation was sought from a small sample of five associate teachers who as qualified and registered teachers had supported students from a range of institutions in the teaching practice components of their teacher education. Data from associate teachers were gathered through individual interviews.

\section{Findings}

Within the overall research findings, academic tasks were identified as a major theme that emerged from the thematic analysis of data from multiple participant samples. The process of coding and categorisation of themes was supported through the use of QSR Nvivo software. The main themes associated with academic tasks are presented and in keeping with the presentation of qualitative data, examples of data will be provided through accompanying vignettes in the respondent's own words.

\section{Academic Discussions}

Academic discussions were favourably associated with exposure to alternative perspectives, the promotion of deepening thinking, and providing an opportunity for feedback. For example, in the following first-year student responses, appreciation is expressed to being exposed to the multiple perspectives of others: "I really like participating in discussions or conversations as you get different perspectives/views from other students and this can help me further develop my learning and understanding". A sentiment also echoed by another first-year student, who said that it was "helpful to hear other people's views, experiences, and opinions; provides different ways of seeing things and dealing with things". Further benefits of academic discussions included enhancing engagement and exposing students to deeper thinking. For instance, in the following example, a first-year respondent identified that academic discussions not only facilitated access to new thoughts and ideas, but could also provide an opportunity for feedback: "I think it is a great idea to open up areas that we 
could discuss that maybe we had not thought of alone. Get new feedback too".

When identified in questionnaire responses, a preference for face-to-face over online was represented in the following first-year student response: "I find online discussions difficult but I am always up for face-to-face when possible". More specific reasons for disliking on-line discussions included digital literacy and the ease with which questions could be asked online, as shown respectively in the following first-year student responses: "I feel that on-line is not for me as I am not ICT literate. However, face-to-face is good as I am able to understand what we discuss in a conversation" and "I prefer face-to-face as you can ask questions easier. I do not like forums and online discussions".

A less consistent response was evident in relation to how discussions could potentially impact self-concepts, such as confidence, efficacy, and worth. Responses in this regard were a mix of both positive and negative outcomes. For example, in relation to instances when discussions had a positive effect, one first-year respondent said, "I think it is great, because it builds confidence in ourselves if we have discussions or conversations together". Conversely, the negative perceptions of academic discussions relating to self-confidence and a sense of personal exposure are identified in the following first-year student response: "I hate it. It is awkward and I am not confident sharing with others".

\section{Academic Writing}

Academic writing was reported as being less favoured than discussions but still preferable over academic reading. Academic writing was reported to potentially increase self-confidence resulting from a sense of achievement. First-year student positive responses towards academic writing included: "I do not mind these as I find I learn quite a bit from researching for my written tasks" and "While I write my knowledge of the related topic expands, I enjoy it". Accomplishing academic written tasks was associated with feelings of personal achievement even if the experience itself was challenging, for instance, one first-year respondent said, "When completed, I feel absolutely stoked that I achieve it", and another first-year respondent commented that academic writing "can be difficult but rewarding and encouraging when you get a good mark". The students also reported that academic writing tasks provided them with acknowledgment of the efforts they put into their learning, as represented by one first-year respondent: "More achievable to have something to show for it when completed rather than reading".

There was however an equal risk of confidence being lowered. Typical generalised negative responses to academic writing included: "I do not exactly like these (essays) and a lot of others experience difficulties with those" and "I understand their value, but I am not a fan". More specific reasons associated with the dislike of academic writing included self-doubt and a lack of confidence. For instance, one first-year respondent said that it was "hard especially when your second guessing yourself and work" and another commented that they experienced "lots of self-doubt but I am more than capable".

According to the teacher educators, academic writing was not just an issue for first-year students and was indeed regarded as challenging even at the later stages of study. One teacher educator said: "By year three, they struggle with academic writing, if they are going to struggle with anything that is what they will struggle with. Being able to put their thoughts down in a clear, concise way that flows".

\section{Academic Reading}

Overall, academic reading was the least favoured academic activity. Learning style and academic skills were identified as affecting engagement in academic reading. Responses from students included expressions, 
such as "hate it", its "got to be done", and "have to do it". For example, first-year responses included "I hate reading", "will skim over and not really take in", and "will get bored and procrastinate", and another first-year student commented that "I struggle with readings-I am sorry I just do not retain it. Probably, because I have never been a reader, I am lucky to pick up a magazine. I find reading really boring". Another first-year student commented on the language of academic reading, saying that "Some reading is well over the top".

Even the teacher educators remarked on how resistant students were to academic reading, for example, in one of the group interviews, one teacher educator said:

For some reason or other, they are not reading enough in order to develop a good knowledge base there. I am amazed at how many students will quite openly admit they actually do not read, they do not like reading so they do not read.

It was further evident in responses that engagement with reading tasks was associated with levels of interest in study in general as well the specific texts themselves. For instance, one first-year student said that whilst overall enjoying study they had limited motivation to read: "I find it very interesting and I do all assignments, hand them in on time. But I do not really engage in class discussions, or read many readings". Likewise, in the interview, an associate teacher commented that "If they are really interested in the academic learning and they want to listen to what you suggest that they maybe go and read further". Another first-year student said identified the importance of reading being meaningful for engagement: "I do not like reading novels, but I enjoy reading tasks for acquiring knowledge. I engage in text when it is meaningful" and conversely, another said, "I like to read but sometimes what we have to read does not interest me".

Both academic reading and writing were regarded as time-consuming which was also associated with challenges such as time-management. The following vignettes provide exemplars of first-year student experiences with academic readings: "I have a hard time trying to read them. But that is all down to time management" and "Not so good, never have enough time". A further response identified academic reading as being "Time-consuming - trying to put in words what I am thinking is hard". Academic language also posed a challenge to students and could act as a barrier between student attitudes towards study and hence engagement. The following first-year student response from one student clearly portrays the negative feelings associated with the language of academic readings "(I) go cross eyed, complain about why it cannot be said or written so everyone can understand it!! Why does it have to be so flashy? Who are we trying to impress?".

The final-year students were more discerning in their attitudes and tended to identify specific academic tasks of interest. A common factor influencing motivation to engage in academic tasks was level of interest in the topic forming the focus of the activity, rather than the format or nature of the academic act per se. Academic tasks were attributed more value if they were perceived as aligning well with the professional role of early childhood teacher, such as observations, teaching philosophies, and applied tasks, such as student-led research projects. For example, one final-year respondent said, "Exploration, discovery, preparation, and presentation of my personal philosophy has been by far the most rewarding experience of all" and another final-year respondent said:

An understanding of observation methods and planning has allowed me to better understand planning on interests and the importance of it. Research has also demonstrated the importance of further knowledge gaining and the importance it can have on the environment you work in.

Furthermore, the respondents identified the place academic tasks had on building connections between the 
theory of teaching and the actual practice. For example, one final-year student referred to the role of developing their own teaching practice philosophy and the impact this had on practice: "I began to understand the importance of beliefs and that theory was just confirmation in my beliefs. (It) made learning fun for me". A further final-year respondent particularly emphasised the value of the research paper that was applied in the early childhood centre regarding "seeing it implemented and reflecting positive change". Meanwhile, research enabled the following final-year respondent to recognise his/her independent learning skills: "(I came) to the conclusion that I can teach myself and not just learn in a formal setting".

Time spent in academic study was no guarantee of being more engaged. For instance, whilst some students reported feeling more engaged in the final-year than they were during their first-year of study, for yet others waning levels of immersion in academic study were reported as students reached the final phase of their study. For example, the following final-year respondent commented that "It is nearly the end of three-year degree and it is now starting to feel like it is dragging on" and another final-year respondent said that "I am still interested in ECE and believe I will continue to work within it for at least 10 years, but I am definitely finding myself a lot less interested as time goes on".

Furthermore, an interest in continuing academic study after graduating was limited with the majority of final-year students expressing either ambivalence or a total lack of interest. At times, there was a contradiction in responses between the value of academic practice and undertaking further academic study. For example, the following final-year respondent said initially about academic study: "It makes you keep wanting to learn and develop as a meaningful teacher". However, later in the questionnaire, the same respondent claimed, "I will never study again!! (Well, that is how I am feeling at the moment)".

\section{Rewarding Academic Tasks}

The most rewarding academic tasks were those that related specifically to professional practice as a teacher. For instance, tasks associated with student (action) research, observation applied in the teaching context, pedagogical documentation and planning for children's learning, and cultural learning in relation to Te Ao Māori (the Māori world). For example, one final-year respondent valued academic tasks that "involve observing, analysing children, and working with peers. Then applying academic learning to the situation". A further final-year respondent went into detail as to the applied nature of a task: "We were required to plan and extend a child's learning and development based on our observations (running records) and conversations with other teachers and child's family". Finally, in the following vignette, a further final-year respondent identifies the specific value of undertaking research:

(Research) prepared me to think outside the box and has shown me that there are many ways to look at the same events or issues. Ethics has been an area that has increased my professional role as an early childhood teacher.

Support for student perspectives on rewarding academic tasks was evident in teacher educators' responses whereby again less tension between the academic and field of ECE was perceived when there was a sense of practical fit, as expressed by the following participant: "I think that if they are engaged in change making and it is to the benefit of the centre then it is recognised and acknowledged". Furthermore, relevance was also essential to engagement as identified by another teacher educator:

If it is not relevant to what they are doing then they (final-year students) start to question why are they doing it, so to them, it needs to support what they do in their centres or what they plan to do with their future careers. 
The field-based aspect of the initial teacher education programmes enabled teacher educators to build relationships with students, which enhanced understanding of student academic work. Through their knowledge of students in their field-based contexts, teacher educators identified that they were more likely to be able to enhance their understanding of student's academic work. For instance, one teacher educator talked about this in relation to written reflections:

Because you have been to see them, you are reading the reflection through the lens of the context that you know they are working in. I can picture them in a space that they are describing, so it just makes it easier for me to give really good authentic feedback, because I know their context.

However, the nature of a field-based programme of study was identified as complex in terms of finding a balance between academic and practice demands. For instance, the teacher educators expressed concern that increased academic demands were taking students away from and diluting these experiences. Phrases, such as "attached to" rather than "embedded within", were used to describe the place of the practice component of the degrees: "It seems somehow we have moved to a field-based programme, which is a full-time degree programme with some practice attached to it".

\section{Discussion}

The data show that the nature of academic task, levels of interest, and relevance to emerging professional practice are important influences on student academic identity. The core constituent elements of student academic identity were represented in the data with reference being made to aspects of: self-theories through perceptions of self-confidence, self-efficacy, and self-worth; agency beliefs through the impact of time-management on self-regulation and evidence of procrastination; achievement indicators through the sense of personal achievement as well as the value attributed to receiving feedback; and motivation with interest in academic tasks being enhanced when academic tasks and aligned with the context of professional practice. However, student academic identity was identified as being an unpredictable phenomenon.

The specific nature of an academic task was identified as playing a significant contributing role in the unpredictable development of student academic identity. As such, the different academic tasks varied in the part they played in developing student academic identity. For example, discussion tasks allowed academic ways of being, knowing, and doing to be kept somewhat at a distance. This distance is maintained through the use of everyday language systems, interpretations, and expressions in the process of meaning making through being able to talk with peers, bounce ideas off each other, and grapple with alternative perspectives. Whilst focusing on a study-related issue, discussion with peers does not mean that academic Discourse is being engaged with. Instead, discussion tasks may permit students to remain within their known Discourse base- their discursive comfort zone. The positioning of peers as co-constructors of knowledge within the act of discussion can signal equality between participants. In the space of co-construction, students can begin to step into academic Discourse as it is in this shared space of co-action that meaning is made to the content of academic study (Aspelin, 2011). However, it would appear that through discussion-based tasks, opportunity is provided to engage in deeper thinking and the exposure to multiple perspectives; both of which are key aspects of academic Discourse. Therefore, it can be surmised that discussion-based activities provide worthy opportunities to transition students into academic Discourse at the point where they reside at the periphery of the academic community (Gee, 2001; Smith, 2009; Wenger, 1998). 
The challenge to discussion tasks came when they took place within online environments, which as well as posing technical challenges also moving discussion out of the verbal and into the textual realm. Discussion activities within online contexts position participants differently as thoughts and ideas are necessarily more formularised and then communicated in a less flowing and conversational manner. The relational nature of learning then shifts, especially if online discussion contexts require students to use their "academic voice". Online discussions therefore highlight the role of text within academic Discourse and the development of an academic identity. Through academic writing, students begin to use an academic voice and not their everyday voice. Hence, there is potential for the level of discursive dissonance to increase due to the degree of disparity between everyday Discourse and academic Discourse. For instance, the qualities of academic Discourse that cause tension are identified as "verbal economy, logical coherence, clarity, dispassionate demeanour, comprehensiveness, and certainty" (Gergen, 2011, p. 222). Challenges with academic writing were associated in part with students being able to take on board this way of writing and replicate in their own writing. Therefore, being able to not only recognise but then also replicate discursive expectations of a social group is significant to developing a sense of identity with that group.

Academic reading and writing place different demands on students in relation to engagement with academic genres (Aranha, 2009). Compared with discussions and writing, reading is a relatively passive enterprise in that it does not allow an actual exchange of communication directly between author and audience within the creation and dissemination of knowledge. The distance between creator and receiver is not enhanced by the nature of academic language itself. A point well represented by the words of Gergen (2011):

The flat formality establishes a barrier. The reader is effectively informed, "I will reveal nothing personal to you, because ultimately you mean little to me", or more dramatically, "I am primarily interested in your admiration". Further, I am not invited to have a voice in the issues at hand. The logic is complete within itself; it strives to reach a conclusion that is so perfectly developed that the readers admiration and sense of inferiority are sufficient to the day. (p. 223)

In a discussion, the participants can for instance question, challenge, and clarify. In the act of reading academic works, the reader, as audience, is more alone; a passive recipient of a message more dependent on his/her own competency with the Discourse of the academic genre to be able to engage with the content of the reading. Academic reading requires students to become more immersed in academic Discourse, and is different again to discussion or written tasks in relation to how the students are positioned in the discursive process, as represented in Figure 2.

Reading of academic text is the primary way in which students are exposed to and become immersed in academic Discourse. Such exposure therefore also breeds familiarity with the disparate qualities of everyday and academic Discourses. A concern when students appear to be so resistant to reading. Through this familiarity, discursive dissonance can potentially be reduced. The students have to not only be on the receiving end of such Discourse but also, as part of the process of acquiring an academic identity, demonstrate the ability to produce work of this same nature. Such production involves the students conveying their academic voice. A primary means of which is through academic writing.

Experience with academic Discourse through time spent in study was no guarantee of a stronger academic identity. Rather, it was the relevance of academic tasks to the future goal and sense of self that held significance. Tasks only requiring reference to theoretical knowledge left students feeling disconnected and unanchored, typically resulting in lower student performance. Students were far more able and willing to engage with 
academic tasks requiring them to situate their knowledge within the experiences of their own teaching practices in the early childhood centre. This aligns with the claim that "Personal interpretations of events, not events in themselves, constitute a person's reality" (Berzonsky, 2004, p. 305). Within this line of argument, it is the student's subjective interpretation of an academic experience which holds significance, not the academic task itself, which may further explain the unpredictability in the development student academic identity. In this way, experiences for some people act as doors opening to new possibilities in terms of self, whereas for others, experience of the same event can act as a barrier to potential success (Yoder, 2000).

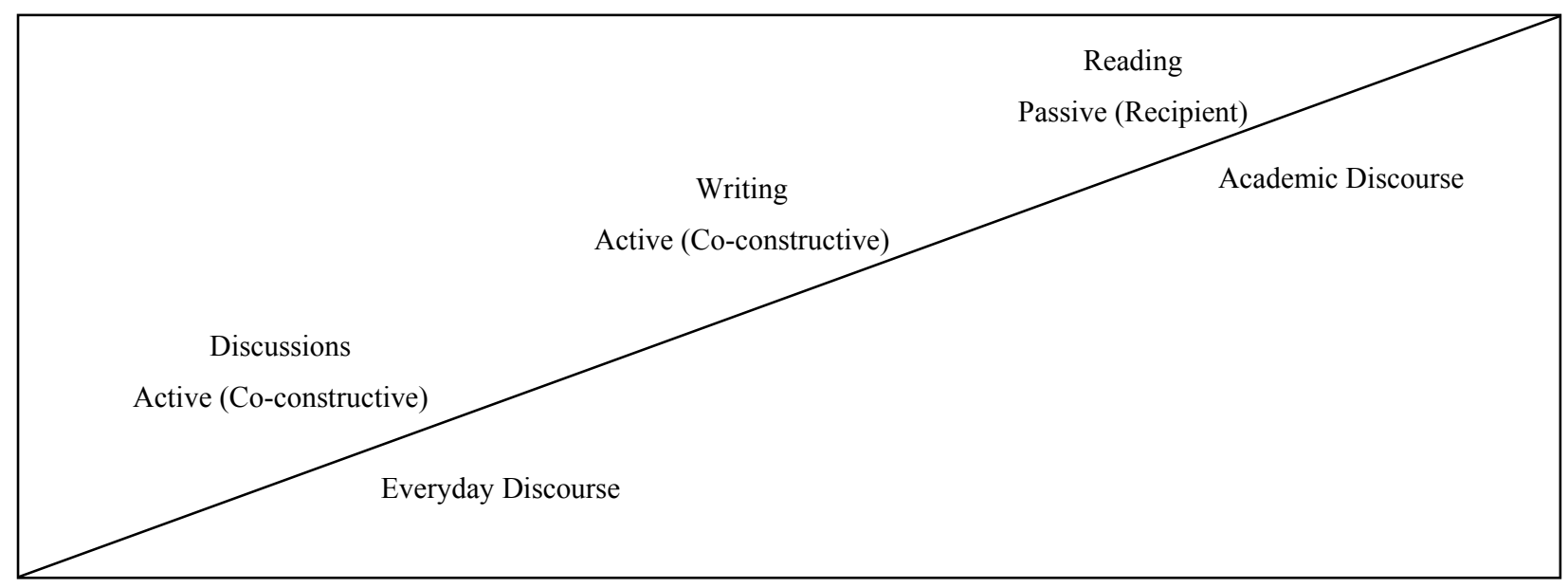

Figure 2. Academic task and immersion in academic Discourse.

The data show that rewarding academic tasks were more likely to be those associated with professional practice; reflecting a stronger identification with the professional rather than the academic domain. This is in keeping with undertaking study for credential purposes but does highlight the challenges facing field-based programmes with the academisation of initial teacher education in Aotearoa. Balancing the demands of academic requirements with those of practice and building relevancy are an important part of curriculum design and as such play an influencing role in the development of student academic identity. Furthermore, academic related learning was not widely considered for on-going learning, with preference reported for non-credit bearing professional development. The academic seemingly being tolerated for the purposes of initial credentialing with emerging professional identities holding more influence within a sense of future self.

\section{Conclusion}

This paper highlights the unpredictability in the development of student academic identity and variability of student engagement in academic Discourse. The nature of academic tasks was identified as contributing to this identity process with some academic tasks calling for more engagement with academic Discourse than others. Overcoming discursive dissonance and stepping out from a zone of comfort with everyday ways of being, knowing, and doing calls for well considered curriculum design and exposure to academic Discourse. This is particularly the case with field-based programmes of study, which draw on applied pedagogies (Downing \& Herrington, 2013), with relevance to academic processes emerging from their alignment with practice requirements and realities.

Student engagement with field-based study is ultimately driven by a desire for professional credentialing 
with students valuing the opportunity to apply learning within professional practice contexts. As such, the academic aspect of the learning experience can be become a tolerated part of achieving this ultimate professional goal. Academic identity, therefore, seems to be more precarious within field-based programmes of study and may require more careful consideration if the academisation of initial teacher education in Aotearoa continues. The precarious social position of early childhood teachers within wider Aotearoa society continues to pose a challenge for programme development. As the academe has taken on the role of providing authority and legitimacy to the credentialing process, sufficient attention needs to be maintained to the challenge of developing new identities through the navigation of academic and practice Discourses.

\section{References}

Aranha, S. (2009). The development of a genre-based writing course for graduate students in two fields. In C. Bazerman, A. Bonini, \& D. de C. Figueiredo (Eds.), Genre in a changing world (pp. 543-564). Fort Collins, C.O.: WAC Clearinghouse; Parlor Press. Retrieved from http://www.scribd.com/doc/207813385/Ch-Bazerman-a-Bonini-D-Figueiredo-2009-Genre-in -a-Changing-World

Aspelin, J. (2011). Co-existence and co-operation: The two-dimensional conception of education. Education, 1(1), 6-11. doi: $10.5923 /$ j.edu. 20110101.02

Azar, F. S. (2013, 11-12 March). Self-efficacy, achievement motivation and academic procrastination as predictors of academic achievement in pre-college students. In Proceeding of the Global Summit on Education 2013, Kuala Lumpur, Malaysia. Retrieved from http://worldconferences.net/proceedings/gse2013/papers_gse2013/071\%20Firouzeh\%20Sepehrianazar.pdf

Bandura, A. (1995). Self-efficacy in changing societies. Cambridge, U.K.: Cambridge University Press.

Barnett, R. (2007). A will to learn: Being a student in an age of uncertainty. Maidenhead, U.K.: Open University Press.

Berzonsky, M. D. (2004). Identity processing style, self-construction, and personal epistemic assumptions: A social-cognitive perspective. European Journal of Developmental Psychology, 1(4), 303-315. doi: 10.1080/17405620444000120

Brown, S., \& Race, P. (2012). Using effective assessment to promote learning. In L. Hunt, \& D. Chalmers (Eds.), University teaching in focus: A learning-centred approach (pp. 74-91). Australia: Australian Council for Educational Research.

Brownlee, J., \& Berthelsen, D. (2006). Personal epistemology and relational pedagogy in early childhood teacher education programs. Early Years: An International Journal of Research and Development, 26(1), 17-29. doi: 10.1080/0957514050050 7785

Calarco, J. M. (2011). “I need help!": Social class and children's help-seeking in elementary school. American Sociological Review, 76(6), 862-882. doi: 10.1177/0003122411427177

Cohen, L., Manion, L., \& Morrison, K. (2007). Research methods in education (6th ed.). London, U.K.: Routledge. Retrieved from http://knowledgeportal.pakteachers.org/sites/knowledgeportal.pakteachers.org/files/resources/RESEARCH\%20 METHOD\%20COHEN\%20ok.pdf

Downing, J., \& Herrington, J. (2013). Applied learning in online spaces: Traditional pedagogies informing educational design for today's learners. In H. Carter, M. Gosper, \& J. Hedberg (Eds.), Electric Dreams: Proceedings Ascilite 2013 Sydney (pp. 236-246). Retrieved from http://www.ascilite.org/conferences/sydney13/program/papers/Downing.pdf

Dweck, C. S. (2000). Self-theories: Their role in motivation, personality, and development. Hove, U.K.: Taylor \& Francis Ltd..

Finlay, L. (2009). Debating phenomenological research methods. Phenomenology \& Practice, 3(1), 6-25.

Freeman, L. (2003, November). Where did dispositions come from and what can we do with them? Paper presented at The Second Annual Symposium on Educator Dispositions, Eastern Kentucky University.

Gee, J. (2000). Identity as an analytic lens for research in education. Review of Research in Education, 25(1), 99-125. doi: 10.3102/0091732X025001099

Gee, J. (2001). Literacy, discourse, and linguistics: Introduction and what is literacy? In E. Cushman, E. Kintgen, B. Kroll, \& M. Rose (Eds.), Literacy: A critical sourcebook (pp. 525-544). Boston, M.A.: Bedford/St. Martin's.

Gergen, K. J. (2011). Relational being: Beyond self and community. Oxford, U.K.: Oxford University Press.

Gourlay, L. (2009). Threshold practices: Becoming a student through academic literacies. London Review of Education, 7(2), 181-192. doi: 10.1080/14748460903003626

Hall, S. (1996). Who needs identity. In S. Hall, \& P. Du Gay (Eds.), Questions of cultural identity (pp. 15-30). London, U.K.: Sage. 
Hamman, D., Gosselin, K., Romano, J., \& Bunuan, R. (2010). Using possible-selves theory to understand the identity development of new teachers. Teaching and Teacher Education, 26(7), 1349-1361. doi: 10.1016/j.tate.2010.03.005

Howell, A. J., \& Watson, D. C. (2007). Procrastination: Associations with achievement goal orientation and learning strategies. Personality and Individual Differences, 43(1), 167-178. doi: 10.1016/j.paid.2006.11.017

Ivanič, R., Edwards, R., Satchwell, C., \& Smith, J. (2007). Possibilities for pedagogy in further education: Harnessing the abundance of literacy. British Educational Research Journal, 33(5), 703-721. doi: 10.1080/01411920701582298

Jackson, D. (2012). Role of academic procrastination, academic self-efficacy beliefs, and prior academic skills on course outcomes for college students in developmental education (Partial completion of doctoral dissertation, University of Georgia).

Kane, R. (2005). Initial teacher education policy and practice: Final report. Wellington, N.Z.: Ministry of Education \& The New Zealand Teachers Council. Retrieved from http:/www.teacherscouncil.govt.nz/sites/default/files/itepolicyandpractice.pdf

Kilgore, D. (2001). Critical and postmodern perspectives on adult learning. New Directions for Adult and Continuing Education, 89(Spring), 53-61.

Krause, K., Bochner, S., \& Duchesne, S. (2003). Educational psychology for learning and teaching. Southbank, Australia: Thomson.

Ladkin, D. (2005). "The enigma of subjectivity": How might phenomenology help action researchers negotiate the relationship between "self", "other" and "truth"? Action Research, 3(1), 108-126. doi: 10.1177/1476750305049968

Lai, E. (2011a). Metacognition: A literature review (Research Report). Retrieved from http://www.pearsonassessments.com/hai/ images/tmrs/Metacognition_Literature_Review_Final.pdf

Lai, E. (2011b). Motivation: A literature review (Research Report). Retrieved from http://www.pearsonassessments.com/hai/ images/tmrs/Motivation_Review_final.pdf

Lea, M. (1998). Academic literacies and learning in higher education: Constructing knowledge through texts and experiences. Studies in the Education of Adults, 30(2), 156-171.

Lea, M. (2004). Academic literacies: A pedagogy for course design. Studies in Higher Education, 29(6), 739-756. doi: $10.1080 / 0307507042000287230$

Lea, M., \& Street, B. (1998). Student writing in higher education: An academic literacies approach. Studies in Higher Education, 23(2), 157-173. doi: 10.1080/03075079812331380364

LeCourt, D. (2004). Identity matters: Schooling the student body in academic discourse. Albany, N.Y.: State University of New York Press.

Markus, H., \& Nurius, P. (1986). Possible selves. American Psychologist, 41(9), 954-969.

Mezirow, J. (2000). Learning to think like an adult: Core concepts of transformation theory. In J. Mezirow, \& Associates (Eds.), Learning as transformation: Critical perspectives on a theory in progress (pp. 3-33). San Francisco, C.A.: Jossey-Bass.

Ministry of Education. (2002). Pathways to the future: Nga- Huarahi Arataki: 2002-2012: A 10 year strategic plan for early childhood education. Wellington, N.Z.: Ministry of Education.

Northedge, A. (2003). Enabling participation in academic discourse. Teaching in Higher Education, 8(2), 169-180. doi: 10.1080/1356251032000052429

Patton, M. (2002). Qualitative research and evaluation methods (3rd ed.). Thousand Oaks, C.A.: Sage Publications.

Perry, K. (2012). What is literacy? A critical review of sociocultural perspectives. Journal of Language and Literacy Education, 8(1), 50-71. Retrieved from http://jolle.coe.uga.edu/wp-content/uploads/2012/06/What-is-Literacy_KPerry.pdf

Reveles, J. M., \& Brown, B. A. (2008). Contextual shifting: Teachers emphasizing students' academic identity to promote scientific literacy. Science Education, 92, 1015-1041. doi: 10.1002/sce.20283

Rodriguez, C. M. (2009). The impact of academic self-concept, expectations and the choice of learning strategy on academic achievement: The case of business students. Higher Education Research \& Development, 28(5), 523-539. doi: 10.1080/07294360903146841

Ryan, R. (2009). Self-determination theory and wellbeing (WeDResearch Review). Retrieved from http://www.welldev.org.uk/ wed-New/network/research-review/Review_1_Ryan.pdf

Schunk, D., \& Mullen, A. (2013). Study skills. In International guide to student achievement (pp. 434-436). New York, N.Y.: Routledge.

Schutz, A. (1967). The phenomenology of the social world. Evanston, I.L.: Northwestern University Press.

Smith, M. (2009). Communities of practice. In The encyclopaedia of informal education. Retrieved from http://www.infed.org. biblio/communities_of_pracrice.htm 
Stets, J., \& Burke, P. (2005). A sociological approach to self and identity. In M. R. Leary, \& J. Tangney (Eds.), Handbook of self and identity (1st ed., pp. 128-152). New York, N.Y.: Guilford Press.

Street, B. (2003). What's "new" in new literacy studies? Critical approaches to literacy in theory and practice. Current Issues in Comparative Education, 5(2), 77-91. Retrieved from http://devweb.tc.columbia.edu/i/a/document/25734_5_2_Street.pdf

Timperley, H. (2013). Feedback. In International guide to student achievement (pp. 402-404). New York, N.Y.: Routledge.

Topp, W. (2000). Knowledge system diagnostics: Applying Foucault's archaeological framework to organizations. Systems Research and Behavioral Science, 17(4), 365-374.

Van Manen, M. (1997). Researching lived experience: Human science for an action sensitive pedagogy (2nd ed.). London, U.K.: Althouse Press.

Vermunt, J. D. (2005). Relations between student learning patterns and personal and contextual factors and academic performance. Higher Education, 49(3), 205-234. doi: 10.1007/s10734-004-6664-2

Walls, T. A., \& Little, T. D. (2005). Relations among personal agency, motivation, and school adjustment in early adolescence. Journal of Educational Psychology, 97(1), 23-31. doi: 10.1037/0022-0663.97.1.23

Was, C. A., Al-Harthy, I., Stack-Oden, M., \& Isaacson, R. (2009). Academic identity status and the relationship to achievement goal orientation. Electronic Journal of Research in Educational Psychology, 7(2), 627-652.

Wenger, E. (1998). Communities of practice: Learning, meaning, and identity. Cambridge: Cambridge University.

Wenger, E. (n.d). Communities of practice: A brief introduction. Retrieved from http://wenger-trayner.com/theory/

Yin, R. (2009). Case study research: Design and methods (4th ed.). Los Angeles, C.A.: Sage Publications.

Yoder, A. E. (2000). Barriers to ego identity status formation: A contextual qualification of Marcia's identity status paradigm. Journal of Adolescence, 23(1), 95-106. doi: 10.1006/jado.1999.0298

Zimmerman, B. (2002). Becoming a self-regulated learner: An overview. Theory Into Practice, 41(2), 64-70. 